\title{
Markov process reliability model for photovoltaic module failures
}

\author{
Loredana Cristaldi, Mohamed Khalil, Marco Faifer \\ Dipartimento di Elettronica, Informazione e Bioingegneria, Politecnico di Milano, Milano 20133, Italy
}

\section{ABSTRACT}

This paper presents a Markov process reliability model for a photovoltaic module. This model includes all the possible failures associated to the operation of a Photovoltaic (PV) module. Failure modes are identified in detail, afterwards all the possible failure states of the PV module during the service are considered. Finally, a complete Markov process is attained to assess the probability of each failure mode occurrence and estimate the mean time to failure, probability density function of the time to module failure, hazard and survival functions of a PV module.

\section{Section: RESEARCH PAPER}

Keywords: failure analysis; Markov process; photovoltaic module; reliability model

Citation: Loredana Cristaldi, Mohamed Khalil, Marco Faifer, Markov process reliability model for photovoltaic module failures, Acta IMEKO, vol. 6, no. 4, article 19, December 2017, identifier: IMEKO-ACTA-06 (2017)-04-19

Section Editor: Lorenzo Ciani, University of Florence, Italy

Received: October 13, 2016; In final form October 6, 2017; Published December, 2017

Copyright: ( 2017 IMEKO. This is an open-access article distributed under the terms of the Creative Commons Attribution 3.0 License, which permits unrestricted use, distribution, and reproduction in any medium, provided the original author and source are credited

Corresponding author: Mohamed Khalil, e-mail: mohamedmahmoud.khali@@polimi.it

\section{INTRODUCTION}

Photovoltaic (PV) systems are installed all around the world to produce electricity from solar energy. The evaluation of their long-term reliability is one of the fundamental values of their assets [1] and should be inclusive of both a complete and partial outage of PV systems in addition to their operation at a level below expectations. In the last years, PV systems have been changing from small isolated systems to large grid-connected power stations. Therefore, any failure associated with PV modules can affect the overall performance of the power system and generate safety issues. Consequently, comprehensive studies have been carried out to explain the failures of PV modules. For instance, Quintana et al. [2] reported the different degradation mechanisms of aged PV modules in the field, Chattopadhyay et al. [3] presented an analysis of degradation data of the Indian survey on PV modules, Cristaldi et al. [4] proposed a diagnostic monitoring architecture based upon the analysis of the PV module failure causes, and a detailed failure analysis of PV module was reported by an international energy agency in [5], etc. Based on the available studies, seven main failure causes for a PV module can be identified in the field: dust, host spot, corrosion, cell cracks, semiconductor ageing, and broken interconnects and soldier busses. PV encapsulation failures contribute as well in the failure of PV modules. This includes encapsulation delamination, discoloration, moisture ingress, and module broken glass. The failures of module encapsulation are excluded in this analysis in order to have a clear view on the reliability of the PV module without the encapsulation. This will allow the manufacturers and decision-makers to have the capability to enhance the lifetime of PV modules separately. In addition, it will provide them with a clear view on the impact of each failure mode on PV reliability, and probability of occurrence for each failure mode.

Different techniques from the literature were used to estimate the PV module reliability. For instance, Charki et al. [6] and Lorande et al. [7] used a Petri network to represent the failures of various components in a PV system and estimate its availability. Theristis et al. [8] constructed a Markov model for a standalone photovoltaic system in order to evaluate Loss of Load Probability (LOLP) based upon the failure and repair rate of each component in the system. Zini et al. [9] used a fault tree technique in order to understand the impact of Balance of System (BOS) components on the system overall reliability. Reliability block diagrams were considered in [10], [11] to measure loss of load probability, availability, and capacity, associated with the performance degradation in PV systems. 
Generally, two different reliability scenarios are widely encountered during the useful life time and wear out phase of systems based on the warranty limits. The first scenario is related only to the full performance so any failure within the PV modules will have a significant impact on reducing the whole system output below the warranty limits. As a result, the system states associated with these failures will be treated as a down state, and these failures are called reliability failures. The second scenario considers the degrade performance as up states, and the associated failures are called durability losses or soft failures. This is applicable as long as the performance of the PV module meets the warranty limits. Both scenarios are based on nonrestorable systems and contain only transitions in the direction towards system failures. More details on reliability failures and durability losses are available in [12], [13]. In this paper, the second scenario is highlighted. For the purpose of abbreviation, the term 'failure' refers to 'soft failure'.

In this work, a complete framework for evaluating the reliability of PV modules using a Markov process is presented based on the aforementioned failure causes. It is aimed to estimate the reliability of the system on the long-term and the probability of each failure mode occurrence, in addition to the calculation of the probability density function, hazard rate, and mean time to failure (MTTF) of a PV module. It is very important to mention that the whole framework is distinct from the general reliability modelling methodologies in [14], as the operational and reliability aspects of photovoltaic modules are considered based upon the failures that affect performance requirements. Moreover, the Markov model processed, in this work, is totally different from the one in [8] whose authors provided a component transition diagram to measure the Loss of Load Probability (LOLP) based on the failure and repair rates of each component in a standalone PV system. In our analysis, a Markov model on the different failure modes of PV module components is constructed, regardless the PV system arrangement, in order to measure the previously mentioned reliability indices, where the failure rates of these failure modes are the transition rates between the different functional states of the PV module component.

Monitoring activities are essential for repairable systems and components with high probability of failures. However, PV modules cannot be repaired, and they are replaced once they fail. Therefore, it is quite hard to implement the necessary monitoring activity, especially if the PV plant is not easily accessed by the maintenance crew. The proposed Markov model can be used as a statistical tool to measure the failure frequency once the probabilities of occurrence are estimated [14] in addition to the contribution of each failure mode in the failure frequency of the system.

A Markov Process is a stochastic process that allows to model systems characterized with several states and the transitions between states. For a random variable $X(t)$ that denotes the state of the system at time $t$ and the collection of all possible states is called state space denoted by $\{X=0,1, . ., r\}$, the conditional probability of the state $X(s)=i$ at time $s$ to be at state $j$ at time $t+s$ is:

$$
P\{X(t+s)=j \mid X(s)=i, X(u)=x(u), 0 \leq u \leq s\}
$$

Equation (1) shows the necessity to know the past history of the process to know the current state. However, a Markov process requires only the knowledge of the current states regardless the past history of the system as shown in (9). This feature is an advantage of using a Markov process.

Through this work, manufacturers and designers will have a clear view on the reliability indices of PV modules in order to have more reliable PV modules at the end of the design phase. In addition, it assists decision makers during the operational phase to enhance the maintenance schedules and monitoring strategies by prioritizing the failure modules in terms of their occurrence and their impact on the functional reliability of PV modules.

This paper is organized as follows: Section 2 presents the different failure modes of PV module, Section 3 introduces the Markov Process. Section 4 discusses the Markov analysis of module failures and Section 5 presents the reliability evaluation of PV module. Finally, Section 6 includes conclusions.

\section{PV MODULE FAILURES}

A PV module consists of solar cells interconnected together by ribbons, and an encapsulant material to protect the components of a PV module from foreign impurities and moisture. The failure causes of PV modules are briefly described in the following subsections.

\subsection{Dust}

The accumulation of dust on the PV module's surface area can produce spots with varying concentrations. These spots vary in shape, location and concentration density. The variation in dust accumulation in any place can lead to different transmittance of light into the module. This will result in small random areas on the PV module with less exposure to solar radiation [15], [16].

Dust deposition depends on its density and size distribution [17]; accordingly, the average degradation of a PV module performance due to dust fouling is not uniform and highly dependent upon the location and weather conditions. For instance, Elminir et al. [18] observed a reduction in PV output power up to $17.4 \%$ per month in a separate field experiment in Egypt during the months of December 2004 to June 2005 while Kymakis et al. [19] monitored the performance of a PV park in Crete for one year and they found out the soiling losses were 4 $5 \%$ during the winter and 6-7\% during the summer period. Cabanillas et al. [20] observed a reduction of modules power up to $13 \%$ within 3 months in Mexico. On the other hand, experimental investigation on the reduction of the PV output efficiency presented in [21] shows that the reduction of efficiency reached up to $11.6 \%$ when the dust deposition density was fixed at about $8 \mathrm{gm}^{-2}$.

Although dust is a detrimental agent whenever solar-energy applications are concerned, in literature reviews in [22], [23], all the attention was given to estimate the degradation rate of a PV module, in short periods up to one year, and no studies are available for the failure rate of the dust when the output power is below the expectations. Accordingly, the failure rate of dust, in the work is calculated based on two important performance parameters: the guaranteed output power and the annual degradation rate under the effect of dust.

Currently, many warranties guaranty that the output power will be at least $90 \%$ of its initial nominal power in 10-12 years and reaches $80 \%$ after $20-25$ years. Consequently, if the output 
power is below $80 \%$ of the nominal power, the PV module fails [24].

Regarding the degradation rate, an interesting six-year experimental work by Ryan et al. [25] concluded an annual degradation rate of $1.4 \%$, due to dust, that can be considered as an accepted value over long time.

Generally, PV module power follows a Gaussian distribution [26], [27]. Accordingly, the associated probability density function is

$P(p)=\frac{1}{\sqrt{2 \pi} \sigma} \exp \left(-\frac{1}{2}\left(\frac{p-\mu}{\sigma}\right)\right)$

where $p$ is the power of module, $\mu$ is the average power and $\sigma$ is the standard deviation of the PV module's power. As the average power of the PV module decreases linearly versus years of operation [28], [29], the average power can be calculated from,

$\mu(t)=P_{0}-A t$

where $P_{\mathrm{o}}$ is the average power at $t=0, A$ is a parameter that reflects the annual reduction in power such that $A / P_{\mathrm{o}}$ represents the annual degradation rate per year, therefore $A / P_{\mathrm{o}}$ $=0.014$. The value of $\sigma$ can be related to $P_{\mathrm{o}}$ using the concept of manufacturing tolerance for the module output power [24], so $\sigma=0.0167 P_{0}$.

Taking into account the time variation, the power distribution (2) at a defined instant $t$ will fit the following distribution:

$P(p, t)=\frac{1}{\sqrt{2 \pi} \sigma} \exp \left\{-\frac{1}{2}\left(\frac{p-\left(p_{0}-A t\right)}{\sigma}\right)^{2}\right\}$

By definition, $R(t)=1-F(t)$ where $F(t)$ is the cumulative distribution function. Thus,

$R(t)=1-\frac{1}{2}\left[1+\operatorname{erf}\left(\frac{p-p_{0}+A t}{\sigma \sqrt{2}}\right)\right]$

where erf is the gauss error function. Substituting $P=0.8 P_{\mathrm{o}}$, $A=0.014 P_{o}, \sigma=0.0167 P_{\mathrm{o}}$ in (5), gives

$R(t)=0.5-0.5 \operatorname{erf}(0.5928 t-8.4683)$

hence the failure rate function is estimated as follows:

$h(t)=-\frac{\mathrm{d}}{\mathrm{d} t} \ln R(t)=\frac{0.3344 \exp \left[-(0.5928 t-8.5746)^{2}\right]}{0.5-0.5 \operatorname{erf}(0.5928 t-8.4746)}$

\subsection{Corrosion}

Corrosion of the conductive parts of the cells and the interconnections is responsible for the deterioration of the PV module and it happens frequently among the PV modules. For instance, Gobind H. et al. [31] observed a significant corrosion in 31 out of 640 photovoltaic modules at $15 \mathrm{kWp}$ gridconnected photovoltaic system after three years in service. Corrosion results in an increase of ohmic resistance and a decrease of the shunt resistance [30]. In general, it contributes in $45 \%$ of the PV module's failures [32], [33].

\subsection{Hot spots}

Shading conditions, mismatching between cell electrical characteristics, and bypass diode failure contribute in the occurrence of hotspots [34]. In the field, solar cells arrays might be subjected to shadows from predictable sources such as weather and environmental conditions, and unpredictable sources such as bird droppings or fallen leaves. Hot spots in PV modules result in contact delamination, melting of encapsulation layers and cells damage.

\subsection{Broken interconnect and solar buses failures}

Solar cells consist of two basic elements: front and rear contacts, to deliver current to the external circuit. Electrical current is carried by bus strips that are soldered to the front and back contacts. Interconnect breaks occur as a result of thermal expansion and contraction or repeated mechanical stress. Also, kinks in interconnects contribute to breaking of interconnects [35]. Broken interconnects result in short circuited cells and open circuited cells. Moreover, solder bond failures may cause a rise of $10^{\circ} \mathrm{C}$ in the operating temperature of the cell. This increase in temperature will reduce the operational efficiency to about $97 \%$ of the healthy conditions [36].

\subsection{Cells cracks}

Cell cracking is a common problem encountered in photovoltaic modules operation. It may develop through different stages of the module's lifetime: during manufacturing, the soldering induces high stresses into the solar cells [37], [38], and during transport through handling and vibrations [39]. In addition, a module in the field experiences mechanical loads due to wind (pressure and vibrations) and snow (pressure). Cracking of cells occurs at a rate of about $1 \%$ per year. Although $1 \%$ failure rate is small, it leads to significant power degradation; because it causes around 1-10\% open circuit cell failures, a decrease in the filling factor and cells mismatching [40], [41].

Generally, cell cracks are formed in different lengths and orientation. Cracks parallel to busbars have a high probability, 16 to $25 \%$, of generating a potentially separated cell area [42][44]. Consequently, the failure rate of cell cracks parallel to bus bars are only considered in this work.

\subsection{Semiconductor aging of PV material}

Thermal ageing of semiconductors is a result of exposure to UV rays for long intervals of time. High temperature and electric fields experienced by the solar cells in a PV module result in the transport of atoms and ions that cause lattice deformation [45]. The lattice affects the structure of the solar cell and changes the electrical properties of the cell. Therefore, the old PV module performance is reduced due to semiconductor material ageing. Ageing results in an increased series resistance or decreased shunt resistance in addition to antireflection coating deterioration. It is well known that the lifetime of photovoltaic modules follows a Weibull distribution with $\beta=2.6$ [46]. Meanwhile, the lifetimes of semiconductor devices of special applications are expected to be from 50 to 100 years [47]. Taking into account the environmental extremes in which the PV modules operate, $\eta$ is assumed to be 50 years for $\beta=2.6$.

\section{MARKOV ANALYSIS}

The aforementioned failure causes occur during the operation of PV modules and result in poor performance and power losses. Therefore, it is crucial to include these failures in the reliability model. As already stated in the introduction, several reliability techniques were considered in the literature and they highlighted the component failures. In this paper, the Markov process is selected to carry out the functional reliability analysis. Accordingly, the PV module is represented by the number of possible states, where each state represents the occurrence of one or more failures.

Markov chains are sequences of random variables in which the future variable is determined by the present variable and 
independent on the way in which the present state arose from its predecessors. The analysis looks at a sequence of events and analyzes the tendency of one event to be followed by another [14]. This tendency is the probability evaluation of transition from one state to another until the system has reached the final state. Thus, a Markov process is defined by a process $\{p(t), t \geq 0\}$ with state space $X=\{0,1,2,3 \ldots . r\}$ and stationary transition probabilities,

$P_{i j}=\operatorname{Pr}(p(t)=j \mid p(0)=i)$ for all $i, j \in X$

where $P(t)$ is a random variable that denotes the state and belongs to state space $X$.

In this work, the state space is finite, for instance a system of $n$ failures will have $2^{n}$ states. For a process of probability state vector $P(t)=\left[P_{0}(t), P_{1}(t), \ldots . P_{\mathrm{r}}(t)\right]$, the distribution $P(t)$ can be estimated from Kolmogorov forward equation as follows,

$\frac{\mathrm{d} p(t)}{\mathrm{d} t}=p(t) . A$

and

$\sum_{j=0}^{n} p(t)=1$

where $\mathrm{d} P(t) / \mathrm{d} t$ is a vector that represents the state probability $p(t)$ at time $t$, and $A$ is the matrix of failure rates between states. Considering failure rates from a state $i$ to state $j$, the failure rates can be arranged in the matrix form

$$
A=\left(\begin{array}{ccc}
\lambda_{00} & \cdots & \lambda_{0 r} \\
\vdots & \ddots & \vdots \\
\lambda_{r 0} & \cdots & \lambda_{r r}
\end{array}\right)
$$

$A$ is also known as a generator matrix. Its diagonal elements are negative and they represent the rate of staying at the same state. It is worth to mention that the sum of the raw entries is equal to zero.

As the number of possible states is finite, (10) is necessary since the probabilities of all states at any time $t$ should be one and the system can be in one and only one of these states [48]. In case of zero repair rates, i.e. Poisson birth-death process, (9) can be rewritten as

$\frac{d p_{i}(t)}{d t}=-\sum_{i \neq j} \lambda_{i, j} P_{i}(t)+\sum_{i \neq j} \lambda_{j, i} P_{j}(t)$

Through the Markov process, system characteristics can be measured like the state visit frequency, system availability, mean time to failure, probability distribution of failures and system performance.

Although a Markov process, from the theoretical viewpoint, is flexible and versatile, special precautions are necessary to deal with the difficulties of practical applications. The main problem is that the number of system states and possible transitions increases rapidly with the number of events in the system [49] and therefore some assumptions are necessary. The usual assumptions considered by current standards and references, i.e. IEC 61508 [50], IEC-61165 [49], [48], and [14], can be summarized as follows: i) failure and repair rate are constant, ii) failure and repair events are independent, iii) the transition probability from one state to another state occurs within a very small time interval, iv) only one event occurs at the same time. Furthermore, absorbing states can be used as an assumption that helps in numerical mathematical limitations [14], [51]. States are absorbing when they are once reached and the system will remain there forever.

The model states are divided into three groups of states: up, degrade and down, as shown in Figure 1. This kind of models

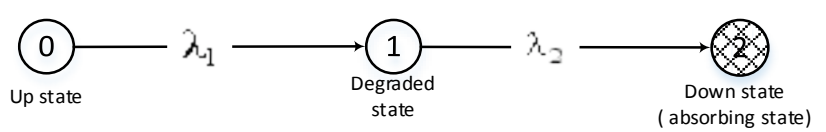

Figure 1. State transition diagram with three states for evaluation of reliability for one element.

with zero repair rate [49] focuses on reliability evaluation $R(t)$, MT'TF, and hazard rate.

The same assumptions and limitations considered in section 3 are followed up:

i) Environmental and operational conditions are constant, consequently, failure rates of different failure causes are constant, with an exception to module aging and dust whose failure rates are affected by the ageing and accumulation factors respectively.

ii) The repair rates, in this model, are equal to zero; because system analysts pay a lot of attention to MTTF; also the failure of a PV module means a replacement.

iii) The degrade state is still an up state. The failures occurrence leads to a drop in PV module performance but still not below the $80 \%$ warranty.

Table 1 illustrates the possible states of a PV module associated with various failures. Although all failure causes are independent, ageing of a PV module is assumed to be a failure which affects the operation of all module states. This is a reasonable accepted assumption if we consider the replacement of the whole PV module as a solution to eliminate that failure. Therefore, each state including ageing failure will be treated as an absorbing state, as shown in Figure 2.

From the state transition diagram in Figure 2 and (12), the state space equations can be written by inspection as shown below:

$P_{0}^{\bullet}(t)=-\left(\lambda_{1}+\lambda_{2}+\lambda_{3}+\lambda_{4}+\lambda_{5}+\lambda_{6}\right) P_{0}(t)$

$P_{1}^{\bullet}(t)=\lambda_{6} P_{0}(t)-\left(\lambda_{1}+\lambda_{2}+\lambda_{3}+\lambda_{4}+\lambda_{5}\right) P_{1}(t)$

$P_{2}^{\bullet}(t)=\lambda_{5} P_{0}(t)-\left(\lambda_{1}+\lambda_{2}+\lambda_{3}+\lambda_{4}+\lambda_{6}\right) P_{2}(t)$

where $P^{\bullet}(t)$ is the rate of change of state probability with respect to time. Absorbing states are of no interest from a reliability point of view, since they are reachable from other states and the limit of their probabilities with respect to time is one:

$\lim _{t \rightarrow \infty} P_{\text {absorbing }}(t)=1$.

According to [52], the 64 states of the Markov process can be reduced into two states: success and failure states, as shown in Figure 3, where the probability of failures is the summation of all down states. Therefore, the absorbing states probability $P_{\mathrm{D}}(t)$ represents the probability the system is down, where $P_{\mathrm{D}}(t)$ is evaluated from:

$P_{\mathrm{D}}(t)=\sum P_{\text {absorbing }}(t)=1-\sum P_{\text {non-absorbing }}(t)$

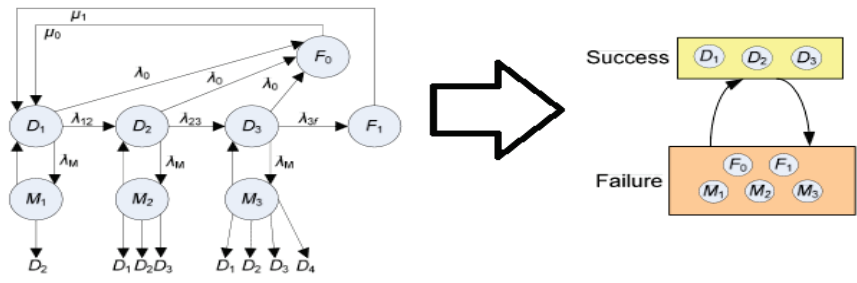

Figure 3. Equivalent Two-state Markov Process from an Eight-state Markov Process [52]. 


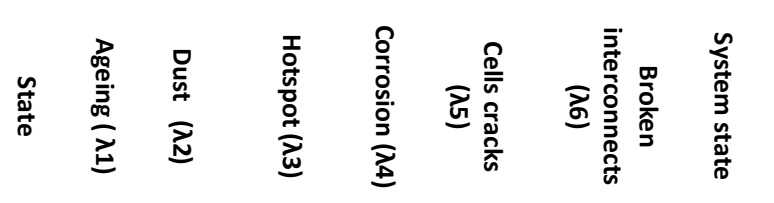

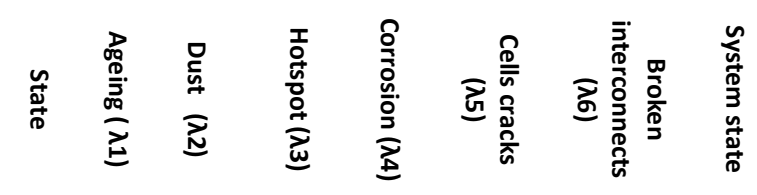

\begin{tabular}{ccllllll}
\hline 0 & $\mathrm{~N}$ & $\mathrm{~N}$ & $\mathrm{~N}$ & $\mathrm{~N}$ & $\mathrm{~N}$ & $\mathrm{~N}$ & $\mathrm{~S}$ \\
1 & $\mathrm{~N}$ & $\mathrm{~N}$ & $\mathrm{~N}$ & $\mathrm{~N}$ & $\mathrm{~N}$ & $\mathrm{Y}$ & $\mathrm{S}$ \\
2 & $\mathrm{~N}$ & $\mathrm{~N}$ & $\mathrm{~N}$ & $\mathrm{~N}$ & $\mathrm{Y}$ & $\mathrm{N}$ & $\mathrm{S}$ \\
3 & $\mathrm{~N}$ & $\mathrm{~N}$ & $\mathrm{~N}$ & $\mathrm{~N}$ & $\mathrm{Y}$ & $\mathrm{Y}$ & $\mathrm{S}$ \\
4 & $\mathrm{~N}$ & $\mathrm{~N}$ & $\mathrm{~N}$ & $\mathrm{Y}$ & $\mathrm{N}$ & $\mathrm{N}$ & $\mathrm{S}$ \\
5 & $\mathrm{~N}$ & $\mathrm{~N}$ & $\mathrm{~N}$ & $\mathrm{Y}$ & $\mathrm{N}$ & $\mathrm{Y}$ & $\mathrm{S}$ \\
6 & $\mathrm{~N}$ & $\mathrm{~N}$ & $\mathrm{~N}$ & $\mathrm{Y}$ & $\mathrm{Y}$ & $\mathrm{N}$ & $\mathrm{S}$ \\
7 & $\mathrm{~N}$ & $\mathrm{~N}$ & $\mathrm{~N}$ & $\mathrm{Y}$ & $\mathrm{Y}$ & $\mathrm{Y}$ & $\mathrm{S}$ \\
8 & $\mathrm{~N}$ & $\mathrm{~N}$ & $\mathrm{Y}$ & $\mathrm{N}$ & $\mathrm{N}$ & $\mathrm{N}$ & $\mathrm{S}$ \\
9 & $\mathrm{~N}$ & $\mathrm{~N}$ & $\mathrm{Y}$ & $\mathrm{N}$ & $\mathrm{N}$ & $\mathrm{Y}$ & $\mathrm{S}$ \\
10 & $\mathrm{~N}$ & $\mathrm{~N}$ & $\mathrm{Y}$ & $\mathrm{N}$ & $\mathrm{Y}$ & $\mathrm{N}$ & $\mathrm{S}$ \\
11 & $\mathrm{~N}$ & $\mathrm{~N}$ & $\mathrm{Y}$ & $\mathrm{N}$ & $\mathrm{Y}$ & $\mathrm{Y}$ & $\mathrm{S}$ \\
12 & $\mathrm{~N}$ & $\mathrm{~N}$ & $\mathrm{Y}$ & $\mathrm{Y}$ & $\mathrm{N}$ & $\mathrm{N}$ & $\mathrm{S}$ \\
13 & $\mathrm{~N}$ & $\mathrm{~N}$ & $\mathrm{Y}$ & $\mathrm{Y}$ & $\mathrm{N}$ & $\mathrm{Y}$ & $\mathrm{S}$ \\
14 & $\mathrm{~N}$ & $\mathrm{~N}$ & $\mathrm{Y}$ & $\mathrm{Y}$ & $\mathrm{Y}$ & $\mathrm{N}$ & $\mathrm{S}$ \\
15 & $\mathrm{~N}$ & $\mathrm{~N}$ & $\mathrm{Y}$ & $\mathrm{Y}$ & $\mathrm{Y}$ & $\mathrm{Y}$ & $\mathrm{S}$ \\
16 & $\mathrm{~N}$ & $\mathrm{Y}$ & $\mathrm{N}$ & $\mathrm{N}$ & $\mathrm{N}$ & $\mathrm{N}$ & $\mathrm{S}$ \\
17 & $\mathrm{~N}$ & $\mathrm{Y}$ & $\mathrm{N}$ & $\mathrm{N}$ & $\mathrm{N}$ & $\mathrm{Y}$ & $\mathrm{S}$ \\
18 & $\mathrm{~N}$ & $\mathrm{Y}$ & $\mathrm{N}$ & $\mathrm{N}$ & $\mathrm{Y}$ & $\mathrm{N}$ & $\mathrm{S}$ \\
19 & $\mathrm{~N}$ & $\mathrm{Y}$ & $\mathrm{N}$ & $\mathrm{N}$ & $\mathrm{Y}$ & $\mathrm{Y}$ & $\mathrm{S}$ \\
20 & $\mathrm{~N}$ & $\mathrm{Y}$ & $\mathrm{N}$ & $\mathrm{Y}$ & $\mathrm{N}$ & $\mathrm{N}$ & $\mathrm{S}$ \\
21 & $\mathrm{~N}$ & $\mathrm{Y}$ & $\mathrm{N}$ & $\mathrm{Y}$ & $\mathrm{N}$ & $\mathrm{Y}$ & $\mathrm{S}$ \\
22 & $\mathrm{~N}$ & $\mathrm{Y}$ & $\mathrm{N}$ & $\mathrm{Y}$ & $\mathrm{Y}$ & $\mathrm{N}$ & $\mathrm{S}$ \\
23 & $\mathrm{~N}$ & $\mathrm{Y}$ & $\mathrm{N}$ & $\mathrm{Y}$ & $\mathrm{Y}$ & $\mathrm{Y}$ & $\mathrm{S}$ \\
24 & $\mathrm{~N}$ & $\mathrm{Y}$ & $\mathrm{Y}$ & $\mathrm{N}$ & $\mathrm{N}$ & $\mathrm{N}$ & $\mathrm{S}$ \\
25 & $\mathrm{~N}$ & $\mathrm{Y}$ & $\mathrm{Y}$ & $\mathrm{N}$ & $\mathrm{N}$ & $\mathrm{Y}$ & $\mathrm{S}$ \\
26 & $\mathrm{~N}$ & $\mathrm{Y}$ & $\mathrm{Y}$ & $\mathrm{N}$ & $\mathrm{Y}$ & $\mathrm{N}$ & $\mathrm{S}$ \\
27 & $\mathrm{~N}$ & $\mathrm{Y}$ & $\mathrm{Y}$ & $\mathrm{N}$ & $\mathrm{Y}$ & $\mathrm{Y}$ & $\mathrm{S}$ \\
28 & $\mathrm{~N}$ & $\mathrm{Y}$ & $\mathrm{Y}$ & $\mathrm{Y}$ & $\mathrm{N}$ & $\mathrm{N}$ & $\mathrm{S}$ \\
29 & $\mathrm{~N}$ & $\mathrm{Y}$ & $\mathrm{Y}$ & $\mathrm{Y}$ & $\mathrm{N}$ & $\mathrm{Y}$ & $\mathrm{S}$ \\
30 & $\mathrm{~N}$ & $\mathrm{Y}$ & $\mathrm{Y}$ & $\mathrm{Y}$ & $\mathrm{Y}$ & $\mathrm{N}$ & $\mathrm{S}$ \\
31 & $\mathrm{~N}$ & $\mathrm{Y}$ & $\mathrm{Y}$ & $\mathrm{Y}$ & $\mathrm{Y}$ & $\mathrm{Y}$ & $\mathrm{F}$ \\
\hline & & & & & & & \\
& & & &
\end{tabular}

\begin{tabular}{llllllll}
\hline 32 & $\mathrm{Y}$ & $\mathrm{N}$ & $\mathrm{N}$ & $\mathrm{N}$ & $\mathrm{N}$ & $\mathrm{N}$ & $\mathrm{F}$ \\
33 & $\mathrm{Y}$ & $\mathrm{N}$ & $\mathrm{N}$ & $\mathrm{N}$ & $\mathrm{N}$ & $\mathrm{Y}$ & $\mathrm{F}$ \\
34 & $\mathrm{Y}$ & $\mathrm{N}$ & $\mathrm{N}$ & $\mathrm{N}$ & $\mathrm{Y}$ & $\mathrm{N}$ & $\mathrm{F}$ \\
35 & $\mathrm{Y}$ & $\mathrm{N}$ & $\mathrm{N}$ & $\mathrm{N}$ & $\mathrm{Y}$ & $\mathrm{Y}$ & $\mathrm{F}$ \\
36 & $\mathrm{Y}$ & $\mathrm{N}$ & $\mathrm{N}$ & $\mathrm{Y}$ & $\mathrm{N}$ & $\mathrm{N}$ & $\mathrm{F}$ \\
37 & $\mathrm{Y}$ & $\mathrm{N}$ & $\mathrm{N}$ & $\mathrm{Y}$ & $\mathrm{N}$ & $\mathrm{Y}$ & $\mathrm{F}$ \\
38 & $\mathrm{Y}$ & $\mathrm{N}$ & $\mathrm{N}$ & $\mathrm{Y}$ & $\mathrm{Y}$ & $\mathrm{N}$ & $\mathrm{F}$ \\
39 & $\mathrm{Y}$ & $\mathrm{N}$ & $\mathrm{N}$ & $\mathrm{Y}$ & $\mathrm{Y}$ & $\mathrm{Y}$ & $\mathrm{F}$ \\
40 & $\mathrm{Y}$ & $\mathrm{N}$ & $\mathrm{Y}$ & $\mathrm{N}$ & $\mathrm{N}$ & $\mathrm{N}$ & $\mathrm{F}$ \\
41 & $\mathrm{Y}$ & $\mathrm{N}$ & $\mathrm{Y}$ & $\mathrm{N}$ & $\mathrm{N}$ & $\mathrm{Y}$ & $\mathrm{F}$ \\
42 & $\mathrm{Y}$ & $\mathrm{N}$ & $\mathrm{Y}$ & $\mathrm{N}$ & $\mathrm{Y}$ & $\mathrm{N}$ & $\mathrm{F}$ \\
43 & $\mathrm{Y}$ & $\mathrm{N}$ & $\mathrm{Y}$ & $\mathrm{N}$ & $\mathrm{Y}$ & $\mathrm{Y}$ & $\mathrm{F}$ \\
44 & $\mathrm{Y}$ & $\mathrm{N}$ & $\mathrm{Y}$ & $\mathrm{Y}$ & $\mathrm{N}$ & $\mathrm{N}$ & $\mathrm{F}$ \\
45 & $\mathrm{Y}$ & $\mathrm{N}$ & $\mathrm{Y}$ & $\mathrm{Y}$ & $\mathrm{N}$ & $\mathrm{Y}$ & $\mathrm{F}$ \\
46 & $\mathrm{Y}$ & $\mathrm{N}$ & $\mathrm{Y}$ & $\mathrm{Y}$ & $\mathrm{Y}$ & $\mathrm{N}$ & $\mathrm{F}$ \\
47 & $\mathrm{Y}$ & $\mathrm{N}$ & $\mathrm{Y}$ & $\mathrm{Y}$ & $\mathrm{Y}$ & $\mathrm{Y}$ & $\mathrm{F}$ \\
48 & $\mathrm{Y}$ & $\mathrm{Y}$ & $\mathrm{N}$ & $\mathrm{N}$ & $\mathrm{N}$ & $\mathrm{N}$ & $\mathrm{F}$ \\
49 & $\mathrm{Y}$ & $\mathrm{Y}$ & $\mathrm{N}$ & $\mathrm{N}$ & $\mathrm{N}$ & $\mathrm{Y}$ & $\mathrm{F}$ \\
50 & $\mathrm{Y}$ & $\mathrm{Y}$ & $\mathrm{N}$ & $\mathrm{N}$ & $\mathrm{Y}$ & $\mathrm{N}$ & $\mathrm{F}$ \\
51 & $\mathrm{Y}$ & $\mathrm{Y}$ & $\mathrm{N}$ & $\mathrm{N}$ & $\mathrm{Y}$ & $\mathrm{Y}$ & $\mathrm{F}$ \\
52 & $\mathrm{Y}$ & $\mathrm{Y}$ & $\mathrm{N}$ & $\mathrm{Y}$ & $\mathrm{N}$ & $\mathrm{N}$ & $\mathrm{F}$ \\
53 & $\mathrm{Y}$ & $\mathrm{Y}$ & $\mathrm{N}$ & $\mathrm{Y}$ & $\mathrm{N}$ & $\mathrm{Y}$ & $\mathrm{F}$ \\
54 & $\mathrm{Y}$ & $\mathrm{Y}$ & $\mathrm{N}$ & $\mathrm{Y}$ & $\mathrm{Y}$ & $\mathrm{N}$ & $\mathrm{F}$ \\
55 & $\mathrm{Y}$ & $\mathrm{Y}$ & $\mathrm{N}$ & $\mathrm{Y}$ & $\mathrm{Y}$ & $\mathrm{Y}$ & $\mathrm{F}$ \\
56 & $\mathrm{Y}$ & $\mathrm{Y}$ & $\mathrm{Y}$ & $\mathrm{N}$ & $\mathrm{N}$ & $\mathrm{N}$ & $\mathrm{F}$ \\
57 & $\mathrm{Y}$ & $\mathrm{Y}$ & $\mathrm{Y}$ & $\mathrm{N}$ & $\mathrm{N}$ & $\mathrm{Y}$ & $\mathrm{F}$ \\
58 & $\mathrm{Y}$ & $\mathrm{Y}$ & $\mathrm{Y}$ & $\mathrm{N}$ & $\mathrm{Y}$ & $\mathrm{N}$ & $\mathrm{F}$ \\
59 & $\mathrm{Y}$ & $\mathrm{Y}$ & $\mathrm{Y}$ & $\mathrm{N}$ & $\mathrm{Y}$ & $\mathrm{Y}$ & $\mathrm{F}$ \\
60 & $\mathrm{Y}$ & $\mathrm{Y}$ & $\mathrm{Y}$ & $\mathrm{Y}$ & $\mathrm{N}$ & $\mathrm{N}$ & $\mathrm{F}$ \\
61 & $\mathrm{Y}$ & $\mathrm{Y}$ & $\mathrm{Y}$ & $\mathrm{Y}$ & $\mathrm{N}$ & $\mathrm{Y}$ & $\mathrm{F}$ \\
62 & $\mathrm{Y}$ & $\mathrm{Y}$ & $\mathrm{Y}$ & $\mathrm{Y}$ & $\mathrm{Y}$ & $\mathrm{N}$ & $\mathrm{F}$ \\
63 & $\mathrm{Y}$ & $\mathrm{Y}$ & $\mathrm{Y}$ & $\mathrm{Y}$ & $\mathrm{Y}$ & $\mathrm{Y}$ & $\mathrm{F}$ \\
\hline & & & & & & & \\
\hline
\end{tabular}

\section{MARKOV PROCESS OF PV MODULE FAILURES}

The manufacturer warranty period typically exceeds 20 years for crystalline silicon modules and 15 years for thin-film modules. Unfortunately, there is little field monitored data and independent accelerated test data available to support most of these warranty claims. The failure rates of PV modules were evaluated and listed in Table 2 . The failure rates are estimated

TABLE 2. PV Module failure rates.

\begin{tabular}{cc}
\hline Failure mode & Parameter \\
\hline Ageing of PV module & $\lambda_{1}=\frac{\beta}{\eta} t^{\beta}$ \\
Dust & $\beta=2.6 ; \eta=50 y r s \quad[46-47]$ \\
Hot spot & $\lambda_{2}=h(t)$ \\
Corrosion & $\lambda_{3}=0.012 y r^{-1}$ \\
Cells cracks & $\lambda_{4}=0.023 y r^{-1}$ \\
Broken interconnect & $\lambda_{5}=0.091 y r^{-1}$ \\
$\&$ soldier bus failures & $\lambda_{6}=0.0031 y r^{-1}$
\end{tabular}

based on the frequency of the PV module failures, noted in literature, for certain population over a determined interval.

\subsection{System state probability}

Based on the state space equations (13) and failure rates in Table 2, the probabilities of PV module states that are associated with one and two simultaneous failure occurrences are shown in Figure 4 and Figure 5, respectively. PV module states associated with more than two simultaneous failure occurrences are avoided because of their low probabilities of occurrence. For example, the state probability of three and four simultaneous failure events ranges from 0 to 0.19 and 0 to 0.025 simultaneously.

Figure 4 shows that cell cracks failure event, represented by system state $P_{2}(t)$ has the highest probability of occurrence and increases steeply. This is due to its high failure rate and its associated significant power degradation. On the other hand, failures due to dust events of state $P_{16}(t)$ occur, as expected, over a large range of operating time because dust is considered one of PV environmental extremes which has its impact on the operation of the PV system as long as the PV module is in service even if its probability of occurrence is small.

Accordingly, the probability of state $P_{18}(t)$, in which cell cracks and dust failure events might occur simultaneously, is 


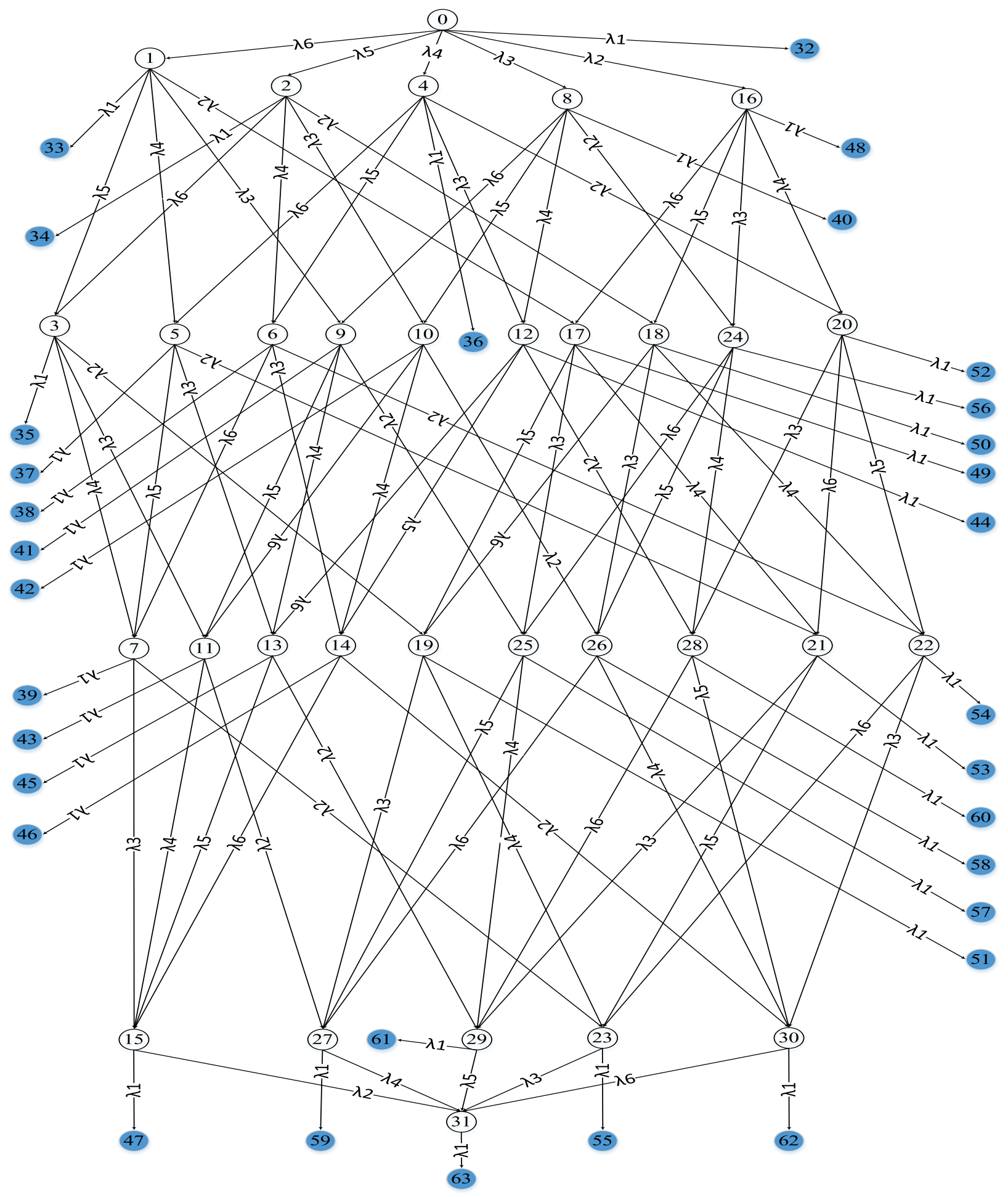

Figure 2. State transition diagram of PV module failure.

very high as shown in Figure 5.

Through Figure 4 and Figure 5, it is possible to measure the probability of each failure mode occurrence after a certain period of operation. For example, Figure 4 shows that the probability of occurrence of dust failure and cells cracks are 0 and 0.4945 , respectively after 10 years of operation. These probabilities of failure occurrence change after 15 years of operation to be 0.1529 and 0.1358 for dust and cells cracks, respectively.

Generally, it can be concluded from Figures 4 and 5 that the more operating years, the higher is the probability of occurrence for states that have more numbers of failure events. The peaks of system states probability curves in Figures 4 and 5 decrease after a certain time because the probability of the PV module being in the absorbing state $P_{\mathrm{D}}(t)$ increases by time.

\subsection{Reliability evaluation}

For a system of states $X$, the up states of the system can be grouped in a set $B$ of functioning sets. The failed states, therefore are grouped into $F=X-B$ of failed states. 


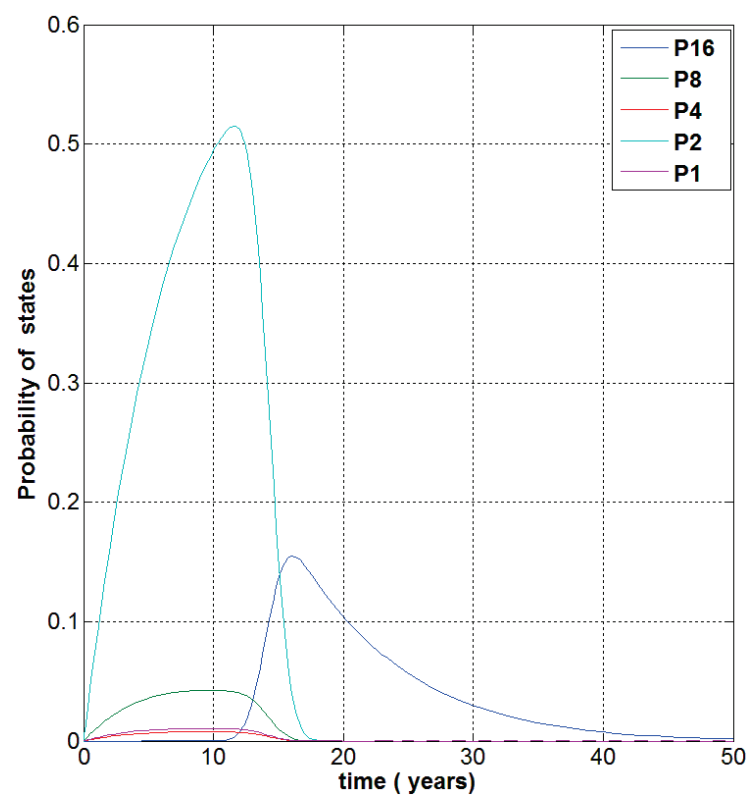

Figure 4. State probability of one failure event.

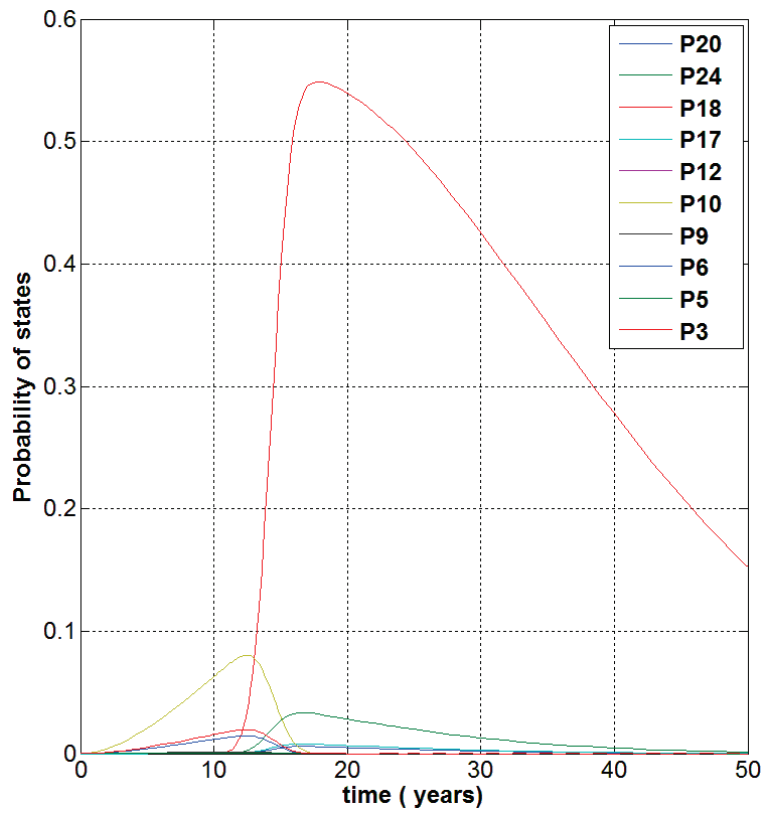

Figure 5. State probability of two simultaneous failure events.

The survivor function $R(t)$ determines the probability that a system does not leave the set $B$ of functioning states during the time interval. Also it can be evaluated from the subtraction of the probability of being into the set $F$ from unity. Thus, the survivor function is:

$R(t)=\sum_{j \in B} P_{j}(t)=1-P_{\mathrm{D}}(t)$

The Probability Density Function (PDF) indicates the distribution of the failure over the entire time range. The larger is the value of $P_{\mathrm{D}}(t)$, the more failures that occur in the small interval time around $t$. If the time to failure has a Probability Density Function, then

$P D F=-\frac{d R}{d t}$

Figure 6 and Figure 7 show the survivor function and the

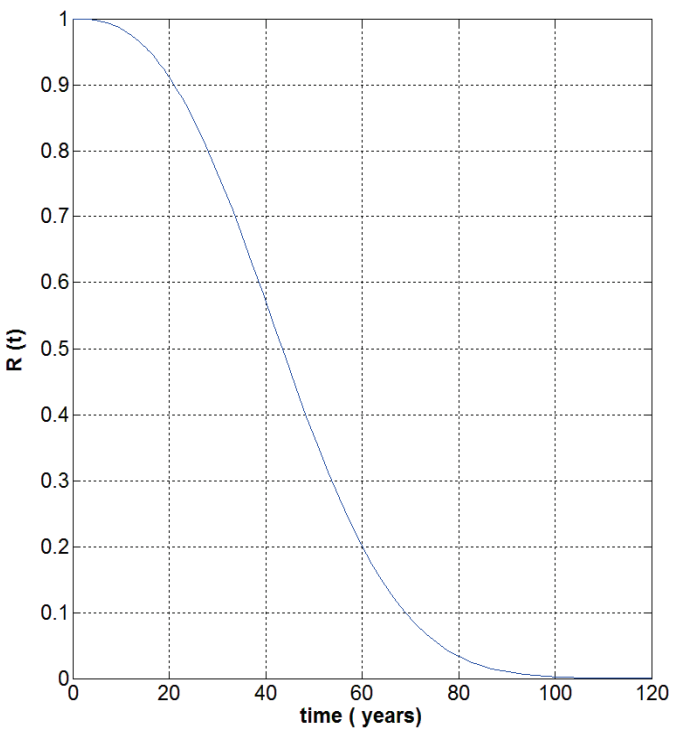

Figure 6. PV module Survivor function.

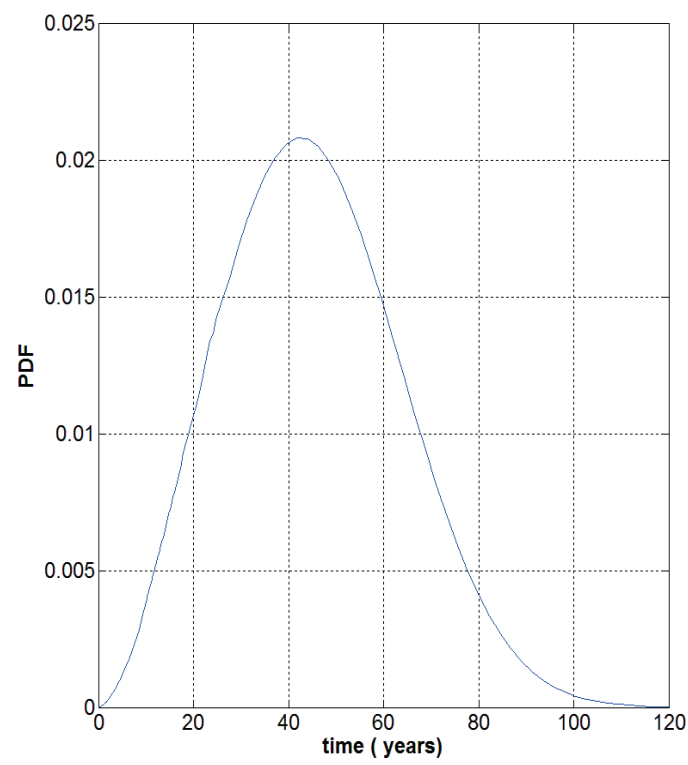

Figure 7. PDF of the time to PV module failure.

Probability Density Function $f(t)$ over the time of the PV module failure, respectively. This is calculated by substituting the failure rates declared in Table 2 into (13). The reliability of the PV module is 0.985 and 0.767 after 10 and 30 years, respectively, as shown in Figure 6.

The MTTF is a basic measure of reliability for non-repairable systems that describes the expected time to failure under specified experimental conditions. MTTF is given by

$$
M T T F=\int_{0}^{\infty} R(t) \mathrm{d} t
$$

Meanwhile the hazard rate $h(t)$ is the instantaneous failure rate, and is defined by

$h(t)=\frac{f(t)}{R(t)}$

The hazard function indicates the change in the failure rate over the life of a population. Figure 8 shows the hazard function of a PV module. By analyzing Figure 8 and (18), it can be noticed that the PV module follows up a constant failure 


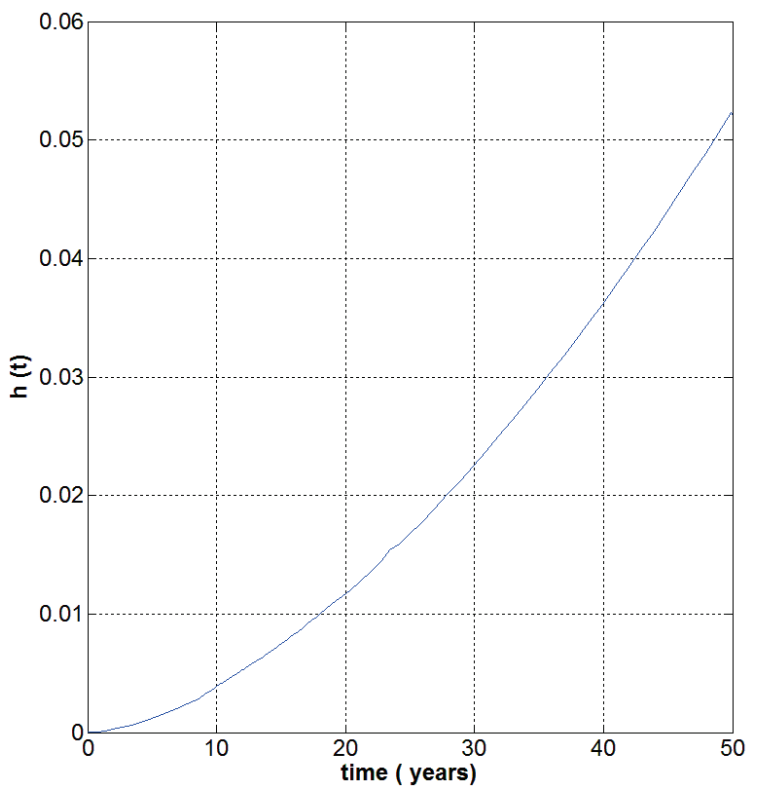

Figure 8. Hazard function of PV module.

rate in the quarter of the first year of the PV module's operation followed by a pronounced wear out behavior.

It is worth to mentioning that the aforementioned PV module reliability results did not include the encapsulate failures in order to have a clear view on the reliability of the PV module only. The encapsulation of the PV module is subjected to failures due to Discoloration and Delamination (D\&D), moisture ingress and module broken glass. A complete separate reliability analysis using a Markov process for failures of a PV module encapsulation is conducted in [55].

The reason behind the very short constant failure rate period is the dust failure that will degrade the output power if the module is left uncleaned.

By applying (17) it results that the MTTF of PV modules is 44.4 years regardless module encapsulation failures. This value is relatively higher than the current warranty periods declared by manufacturers for PV modules.

\section{CONCLUSION}

It is well known that a high degree of reliability needs to identify the possible failure modes of a component or a system. A PV module is a critical component in a PV system. Hence, the different failure modes of PV modules are discussed in detail. A Markov process is used to analyze the probability of occurrence for each failure mode in addition to the evaluation of survivor function, hazard rate, meantime to failure, and probability density function based on these failure modes.

The Markov process shows that cell cracks have a high probability of occurrence. This requires to pay more attention to the technology of cell implementation in the module, the factory tests, and means of transportation to the site. Dust is the dominant failure cause of a PV module along its operating life time and results in a very short useful life time phase, three months, if the PV module is not cleaned. In addition, both dust and cell cracks failures contribute significantly in the probability of two simultaneous failure events. For example, the highest probability for a PV module to have two simultaneous failure events is assigned to both cell crack and dust, $P_{18}$. This is followed by $P_{10}$, where hotspot and cell cracks occur, and $P_{24}$, where dust and hotspot occur simultaneously.

The reliability of a PV module is 0.985 and 0.767 after 10 and 30 years, respectively. Meanwhile, the calculated MTTR is 44.4 years because a PV module follows up the same aging characteristics of semiconductors, when the encapsulation failures are excluded from the PV module reliability analysis. This highlights the impact of encapsulant failures that reduces the lifetime of PV modules to the current values declared by manufacturers.

\section{REFERENCES}

[1] Mougharbel, I.; Makkawi, A.; Ghazal, H., 2012. Optimal solution for the connectivity of PV systems on a scheduled availability of the grid: Case study for Lebanon. Proceedings 2012 International Conference on Renewable Energies for Developing Countries (REDEC). pp.1-5.

[2] Quintana, M.A., King, D.L., McMahon, T.J.; Osterwald, C.R., 2002. Commonly observed degradation in field-aged photovoltaic modules. Proceedings the Twenty-Ninth IEEE on Photovoltaic Specialists Conference. pp.1436-1439.

[3] Chattopadhyay, S., Dubey, R., Kuthanazhi, V., John, J.J.; Solanki, C.S., Kottantharayil, A., Arora, B.M., Narasimhan, K.L. Kuber, V. Vasi, J. Kumar, A. Sastry, 2014. Visual Degradation in FieldAged Crystalline Silicon PV Modules in India and Correlation with Electrical Degradation. IEEE Journal of Photovoltaics 4 (6), 1470-1476.

[4] L. Cristaldi, M. Faifer, M. Lazzaroni, M.M.A. Khalil, M. Catelani, L. Ciani, 2015. Diagnostic Architecture: a procedure based on the analysis of the failure causes applied to Photovoltaic Plants. Measurement (2015).

[5] International Energy Agency (IEA), 2014. Review of Failures of Photovoltaic Modules, External final report IEA-PVPS. ISBN 978-3-906042-16-9.

[6] Charki, A.; Bigaud, D., 2013. Availability Estimation of a Photovoltaic System, Proceedings of annual Reliability and Maintainability Symposium (RAMS). pp.1-5.

[7] R. Lorande, A. Charki, D. Biguad, E.A Elsayed, P. Excoffier, 2011. Reliability and availability estimation of a photovoltaic system using Petri networks.Proceeding of European Safety and Reliability Association (ESREL2011).

[8] Theristis, M.; Papazoglou, I.A., 2014.Markovian Reliability Analysis of Standalone Photovoltaic Systems Incorporating Repairs. IEEE Journal of photovoltaics 4 (1), 414-422.

[9] Gabriele Zini, Christophe Mangeant, and Jens Merten, 2011. Reliability of large-scale grid-connected photovoltaic systems. Renewable Energy36 (9), 2334-2340.

[10] Huffman, D.L.; Antelme, F., 2009. Availability analysis of a solar power system with graceful degradation, proceedings of Reliability and Maintainability Symposium (RAMS). Pp.348-352.

[11] M. Theristis, G. C. Bakos, and I. A. Papazoglou, 2012 .Development of a reliability model for the estimation of the loss of load probability and O\&M cost for an off-grid PV system, Proceedings 27th European Photovoltaic Solution Energy Conference, Frankfurt, Germany. pp. 4245-4248.

[12] T. J. McMahon, G. J. Jorgensen, and R. L. Hulstrom, D. L. King and M. A. Quintana, 2000. Module 30 Year Life: What Does it Mean and Is it Predictable/Achievable?. NCPV program review meeting, Colorado.

[13] Yedidi, K., Tatapudi, S., Mallineni, J., Knisely, B., Kutiche, J., TamizhMani, G, 2014. Failure and degradation modes and rates of PV modules in a hot-dry climate: Results after 16 years of field exposure, Proceedings 40th IEEE Photovoltaic Specialist Conference (PVSC).pp.3245-3247.

[14] Marvin Rausand, Arnljot Høyland, 2004. System Reliability Theory: Models, Statistical Methods, and Applications, 2nd edition, wiley. ISBN: 978-0-471-47133-2.

[15] Dastoori, K., Al-Shabaan, G., Kolhe, M., Thompson, D., Makin, 
B., 2013. Charge measurement of dust particles on photovoltaic module. Proceedings 8th International Symposium on Advanced Topics in Electrical Engineering (ATEE). Pp.1-4.

[16] Qasem, H., Betts, T.R.; Gottschalg, R., 1998. Effect of shading caused by dust on cadmium telluride photovoltaic modules. Proceedings 37th IEEE Photovoltaic Specialists Conference (PVSC). pp. $3199-3204$.

[17] Y. Al-Hasan, 1998. A new correlation for direct beam solar radiation received by photovoltaic panel with sand dust accumulated on its surface. Solar Energy 63, 323-333.

[18] Eliminir HK, Ghitas AE, Hamid RH, Hussainy FE, Beheary MM, Abdel-Moneim KM, 2006. Effect of dust on the transparent cover of solar collectors. Energy Conversion and Management 47, 3192-3203.

[19] Kymakis E, Kalykakis S, Papazoglou TM, 2009. Performance analysis of a grid connected Photovoltaic Park on the island of Crete. Energy Convers Manage 50, 433-438.

[20] R.E. Cabanillas, H. Munguía, 2011. Dust accumulation effect on efficiency of Si photovoltaics modules. Journal of Renewable and Sustainable Energy 3, 043-114.

[21] Hai Jiang, Lin Lu, and Ke Sun, 2011. Experimental investigation of the impact of airborne dust deposition on the performance of solar photovoltaic (PV) modules. Atmospheric Environment Journal 45, 4299-4304.

[22] Travis Sarver, Ali Al-Qaraghuli, Lawrence L. Kazmerski, 2013. A comprehensive review of the impact of dust on the use of solar energy: History, investigations, results, literature, and mitigation approaches. Renewable and Sustainable Energy Reviews 22, 698 733.

[23] M. Mani, R. Pillai, 2010. Impact of dust on solar photovoltaic (PV) performance: research status, challenges and recommendations. Renewable and Sustainable Energy Reviews $14,3124-3131$

[24] Vázquez, M. and Rey-Stolle, I., 2008, Photovoltaic module reliability model based on field degradation studies. Prog. Photovoltaic Res. Applications 16, 419-433. DOI: 10.1002/pip.825.

[25] Ryan CP, Vignola F, McDaniels DK, 1989. Solar cell arrays: degradation due to dirt. Proceedings of the 1989 annual conference. American solar energy society. pp. 234-237.

[26] Reis A.M., Coleman N.T., Marshall M.W., Lehman, P.A. Chamberlain C.E., 2002. Comparison of PV module performance before and after 11-years of field exposure. Proceedings of the 29th IEEE Photovoltaic Specialists Conference, New Orleans, Louisiana, USA. pp. 1432 - 1435.

[27] Sakamoto, S., Oshiro, T., 2003. Field test results on the stability of crystalline silicon photovoltaic modules manufactured in the 1990s. Proceedings of 3rd World Conference on Photovoltaic Energy Conversion. pp. 1888-1891.

[28] Osterwald, C.R., Benner, J.P., Pruett, J., Anderberg, A., Rummeland, S.,Ottoson, L,2003. Degradation in weathered crystalline-silicon PV modules apparently caused by UV radiation. Proceedings of 3rd World Conference on Photovoltaic Energy Conversion, Osaka, Japan. pp. 2911-2915.

[29] Raghuraman B., Lakshman V., Kuitche J., Shisler W., Tamizhmani G., Kapoor H, 2006. An Overview of SMUD's Outdoor Photovoltaic Test Program at Arizona State University. Proceedings of the 2006 IEEE 4th World Conference on Photovoltaic Energy Conversion vol.2. Pp.2214-2216.

[30] Saly V., Ruzinsky M. Packa, J. Redi P., 2002. Examination of solar cells and encapsulations of small experimental photovoltaic modules. Proceedings 2nd International IEEE Conference on Polymers and Adhesives in Microelectronics and Photonics (POLYTRONIC 2002). Pp.137-141.

[31] tmaram, Gobind H., Marion B., Herig C.,1991.Three years performance and reliability of a $15 \mathrm{kWp}$ amorphous silicon photovoltaic system. Proceedings Twenty Second IEEE conference on Photovoltaic Specialists. Pp.600-607.

[32] Osama Hassan, A.F.M. Arif, 2014. Performance and life prediction model for photovoltaic modules: Effect of encapsulant constitutive behavior. Solar Energy Materials and Solar Cells 122, 75-78.

[33] P. Chaturvedi, B. Hoex, T.M. Walsh, 2013. Broken metal fingers in silicon wafer solar cells and PV modules. Sol. Energy Mater. Sol. Cells, 108, 78-81.

[34] Kim K.A., Krein P.T., 2013.Photovoltaic hot spot analysis for cells with various reverse-bias characteristics through electrical and thermal simulation. 14th IEEE Workshop on Control and Modeling for Power Electronics (COMPEL).pp.1-8.

[35] John Wohlgemuth, Daniel W. Cunningham, Andy Nguyen, George Kelly and Dinesh Amin, 2010. Failure Modes of Crystalline Si Modules. PV Module Reliability Workshop 2010, US department of energy solar office. http://www1.eere.energy.gov/solar/pdfs/pvrw2010_wohlgemut h_silicon.pdf

[36] Carroll D., 1991. Cell assembly solder bond examination techniques for high volume production. Procceedings of Photovoltaic Specialists Conference .pp.625-628.

[37] M. Gabor, M. M. Ralli,L. Alegria, C. Brodona ro, J. Woods, L. Felton, 2006. Soldering induced damage to thin Si solar cells and detection of cracked cells in modules. Proceedings of 21 th European Photovoltaic Solar Energy Conference and Exhibition, WIP, Dresden, Germany. pp. 2042-2047

[38] J. Wendt, M. Träger, M. Mette, A. Pfennig, B. Jäckel, 2009. The Link between Mechanical Stress Induced by Soldering and Micro Damages in Silicon Solar Cells. Proceedings 24th European Photovoltaic Solar Energy Conference and Exhibition, WIP, Hamburg, Germany. pp. 3420-3423.

[39] F. Reil, K. Strohkendl, J. Althaus, W. Vaassen, 2009. Mechanische Beanspruchungen für PV Module Transportbelastungen. Photovoltaik-Modultechnik Workshop 6, TÜV Rheinland, Köln, Germany. [In German].

[40] Ronald G. Ross Jr., 1982. Photovoltaic Array Reliability Optimization. IEEE transactions on reliability R-31(3).

[41] Python, M., Dominé, D., Söderström, T., Meillaud, F. and Ballif, C, 2010. Microcrystalline silicon solar cells: effect of substrate temperature on cracks and their role in post-oxidation. Proceedings Photovoltaic: Res. Applications 18. Pp.491-499. Doi: $10.1002 /$ pip. 956

[42] D. DeGraaff, R. Lacerda, Z. Campeau, 2011. Degradation Mechanisms in Si Module Technologies Observed in the Field; Their Analysis and Statistics, Presentation at PV Module Reliability Workshop, NREL, Denver, USA. http://www1.eere.energy.gov/solar/pdfs/pvmrw2011_01_plen_ degraaff.pdf

[43] S. Kajari-Schröder , I. Kunzea, M. Köntges,2012. Criticality of cracks in PV modules. Proceedings of the 2nd International Conference on Crystalline Silicon Photovoltaics (SiliconPV 2012). pp. 658 - 663. doi: 10.1016/j.egypro.2012.07.125

[44] M. Köntges, S. Kajari Schröder, I. Kunze, U. Jahn, 2011.Crack statistic of crystalline silicon photovoltaic modules. proceedings of 26th european photovoltaic solar energy conference and exhibition, hamburg, germany

[45] vikrant sharma,s.s. chandel,2013. performance and degradation analysis for long term reliability of solar photovoltaic systems: a review. renewable and sustainable energy reviews 27, 753-767.

[46] r. laronde, a. charki, d. bigaud, 2011. lifetime estimation of a photovoltaic module based on temperature measurement. proceedings of 2 nd imeko tc 11 international symposium metrological infrastructure, cavtat, croatia.

[47] mary g. priore, 1988. Discrete semiconductor device reliability, reliability analysis center, defense technical information center. http://www.dtic.mil/dtic/tr/fulltext/u2/a208360.pdf

[48] Applied R\&M Manual for Defence Systems GR-77, Part C R\&M Related Techniques, issue 2011.

[49] IEC-61165, 2007. Application of Markov techniques, 2nd Ed.

[50] IEC-61508, 2010. Functional safety of electrical/ electronic/ programmable electronic safety- related systems, 2nd Ed.

[51] Kumar, R.; Jackson, A., 2009. Accurate reliability modeling using 
Markov Analysis with non-constant hazard rates. Proceeding of 2009 IEEE Aerospace conference. pp.1-7. Doi: 10.1109/AERO.2009.4839533.

[52] Haifeng Ge, 2010. Maintenance Optimization for Substations with Aging Equipment (2010).Electrical Engineering Theses and Dissertations. Paper 7

[53] Kontges, M.; Kajari-Schroder, S.; Kunze, I., 2013. Crack Statistic for Wafer-Based Silicon Solar Cell Modules in the Field Measured by UV Fluorescence. IEEE Journal of Photovoltaics 3(1) $95-101$.
[54] Shrestha S.M., Mallineni J.K., Yedidi K.R., Knisely B., Tatapudi S., Kuitche J., TamizhMani G., 2014. Determination of Dominant Failure Modes Using FMECA on the Field Deployed c-Si Modules Under Hot-Dry Desert Climate. IEEE Journal of Photovoltaics 99, 1-9. Doi: 10.1109/JPHOTOV.2014.2366872.

[55] L. Cristaldi, Mohamed Khalil, M. Faifer, Payam Soulatiantork," Markov process reliability model for photovoltaic module encapsulation failures," in 4th international conference on Renewable energy research and applications, Palermo, Italy 22-25 Nov. 2015. 